\title{
Analysis Compressive Strength of Solid Waste Recycling Battery As a Partially Replacing Sand in Concrete
}

\section{Prihantono, Anisah, and Kusno Adi Sambowo}

Building Technical Vocational Education Program, Technical Faculty, State University of Jakarta, Jakarta, Indonesia

\section{Abstract}

The formulation of the problem is whether recycled solid waste is used as a building material to replace some of the sand in making concrete. This study aims to determine the optimum compressive strength of normal concrete by using recycled solid waste as a substitute for some sand. This study uses a cylindrical shaped test object with a diameter of $10 \mathrm{~cm}$ and a height of $20 \mathrm{~cm}$. Solid waste batteries are used with variations of $0 \%, 10 \%, 12.5 \%$ and $15 \%$ for each specimen. Fc'20 MPa, W/ C 0.55, and $12+2$ $\mathrm{cm}$ slump compressive strength, with 48 samples ( 3 specimens for each variation for

Corresponding Author:

Prihantono

Prihantono16@unj.ac.id

Received: 11 January 2019

Accepted: 14 February 2019

Published: 25 March 2019

Publishing services provided by Knowledge E

(c) Prihantono et al. This article is distributed under the terms of the Creative Commons

Attribution License, which permits unrestricted use and redistribution provided that the original author and source are credited.

Selection and Peer-review under the responsibility of the 3rd ICTVET 2018 Conference Committee.

\section{G OPEN ACCESS}

$7.14,28,28$ and 56 days). The results showed that $10 \%$ variation of solid waste recycling battery reached the average concrete compressive strength is $22.08 \mathrm{MPa} ; 12,5 \%$ variation of solid waste recycling battery is $25.69 \mathrm{MPa}$ and $15 \%$ variation of solid waste recycling battery is $18.47 \mathrm{Mpa}$. Optimum compressive strength with $12,5 \%$ variation of solid waste recycling battery is $25.69 \mathrm{Mpa}$.

Keywords: Solid Waste Recycling Batteries, Sand Substitutes, Compressive Strength

\section{Introduction}

The battery which is a power supply component in motor vehicles until now its main component is still from lead metal $(\mathrm{Pb})$ and there is no alternative that can replace it. There are two types of accumulators namely wet accumulators and dry accumulators that have different energy storage strengths. Wet accumulator consists of tin plates $(\mathrm{PbO})$ which are inserted into sulfuric acid solution ( $\mathrm{H} 2 \mathrm{SO} 4)$ and then the tin plates are connected to direct current electric power (DC), the properties will change immediately. One of the plates will be dark brown, which is due to the formation of periokside lead ( $\mathrm{PbO} 2)$. The other plate will be light gray due to the formation of pure tin on the plate $(\mathrm{Pb})$. In the dry accumulator the active ingredients of the positive plates consist of superoxyde-nickel (NiO2) and negative plate containing iron (Fe) [1] 
Recycled solid waste batteries have physical properties in the form of chunks, fine grains such as blackish dust. Based on the test results of the Jakarta State University Concrete Laboratory, the recycling of solid waste batteries has a specific gravity of $2.94 \mathrm{~g} / \mathrm{ml}$. Furthermore, the results of TCLP Laboratory testing of the Ministry of Environment and Forestry, the recycling of used batteries in the $\mathrm{Pb}, \mathrm{Hg}$ and $\mathrm{Zn}$ test parameters are still below TCLP PP No. 101 of 2014, so that recycled solid waste will meet environmental quality standards in terms of the content of heavy metals that are harmful to the environment. Therefore, the utilization of recycled solid waste batteries needs to be studied to determine the performance of waste as an aggregate substitution in the manufacture of concrete, especially in compressive strength.)

Concrete is one of the construction materials that continues to experience development, both in terms of concrete-forming materials and methods of implementation, along with the increasing use of concrete in the construction industry, the more changes or replacement of concrete or concrete modification materials are expected to improve quality concrete and can reduce environmental problems. With the height of BJ used battery waste $2.94 \mathrm{gr} / \mathrm{ml}$ and not including B3 waste type, also containing Pb metal, a research was carried out " Analysis Compressive Strength of Solid Waste Recycling Battery as a Partially Replacing Sand in Concrete "

\section{Methods and Equipment}

\subsection{Methods}

This research method is experimental. The specimens used were concrete from used battery waste as a substitute for some sand with a percentage of waste by $10 \%, 12.5 \%$ and $15 \%$. Where testing is done is the value of concrete compressive strength at the age of 28 and 56 days.

The processing of used battery waste used is the result of sand grain gradation analysis with a standard sieve for concrete products, the recycled solid waste sand passes the number 4 sieve standard with a $4.75 \mathrm{~mm}$ sieve hole. The recycled solid waste of the battery is included in zone II, which is rather fine sand. While the results of the specific gravity test are $2.94 \mathrm{~g} / \mathrm{ml}$. Sand grain grain size analysis according to SNI 3423: 2008

Examination of chemical elements in the sample of recycled solid waste batteries was carried out at the Fire University, Jakarta Engineering and Material Research Laboratory. From the results of the examination of the content of compounds in solid waste, the 


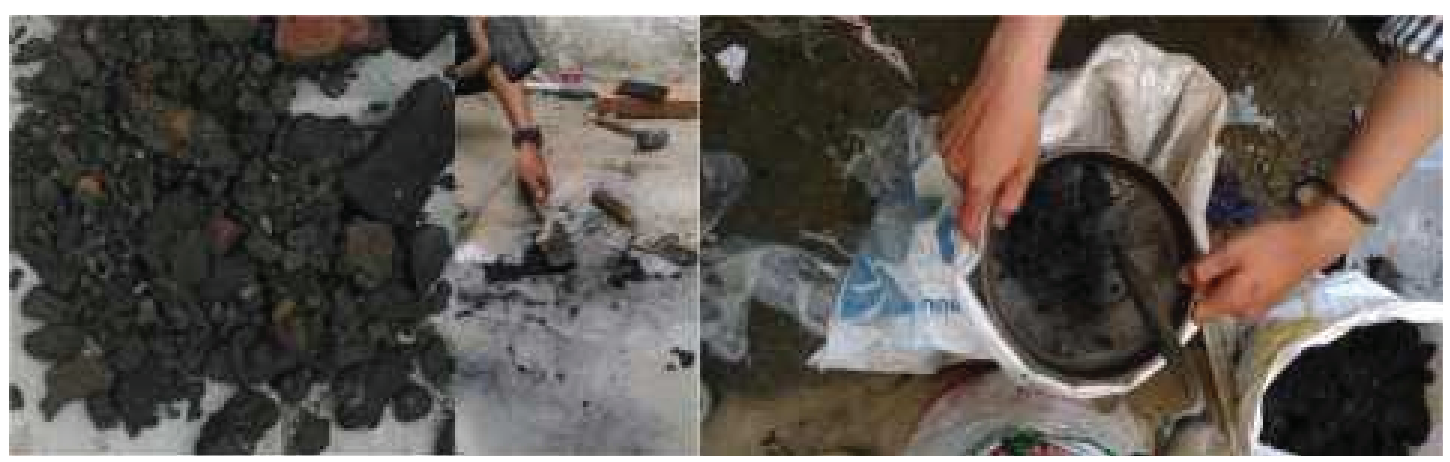

Figure 1: Process of waste sieving.

largest content of the content include $\mathrm{CO} 2, \mathrm{Na} 2 \mathrm{O}$, and Fe2O3. Carbon dioxide (CO2) is commonly used as a work material in fire fighting systems because of the nature of carbon dioxide that will not burn or support combustion. Ferric oxide (Fe2O3) has properties that are not easily soluble in water and are not flammable.

Sodium oxide ( $\mathrm{Na2O}$ ) solubility in water reacts to form $\mathrm{NaOH}$ and can be corrosive. Non-flammable but increases the burning of other substances.

TABLE 1: Result of Solid Waste Recycling Battery Scanning Electron Microscopy (SEM).

\begin{tabular}{l|cc} 
No. & Chemical Composition & Content (\%) \\
1 & $\mathrm{CO}_{2}$ & 36,76 \\
2 & $\mathrm{Fe}_{2} \mathrm{O}_{3}$ & 21,59 \\
3 & $\mathrm{SiO}_{2}$ & 2,48 \\
4 & $\mathrm{Al}_{2} \mathrm{O}_{3}$ & 0,72 \\
5 & $\mathrm{CaO}_{2}$ & 1,73 \\
6 & $\mathrm{SO}_{3}$ & 12,98 \\
7 & $\mathrm{Na}_{2} \mathrm{O}$ & 23,30 \\
8 & $\mathrm{Cr}_{2} \mathrm{O}_{3}$ & 0,02 \\
9 & $\mathrm{SnO}^{2}$ & 0,42 \\
Reference : Fire Research Laboratory, & Material \& Safety \\
Engineering Jakarta State University, 2017
\end{tabular}

Subsequent testing is carried out to determine the harmful chemical elements that can / easily dissolve. This TCLP test can be used to determine the value of elements and chemical compounds that are harmful to human life. TCLP standardization and TCLP results are determined by the government in Government Regulation No. 101 of 2014. The test results in table 2 show that waste is identified as B3 category 2 waste. In category 2 , if the waste has pollutant concentration equal to or less than TCLP-A and more large from TCLP-B as stated in Attachment III of PP No. 101 of 2014.

From TCLP test results, it can be concluded that recycled solid waste batteries meet environmental quality standards in terms of the content of heavy metals that are harmful 
TABLE 2: Results of Battery Recycling Waste Samples.

\begin{tabular}{|c|c|c|c|c|c|}
\hline No. & Parameter & Unit & $\begin{array}{l}\text { Analysis } \\
\text { Method }\end{array}$ & $\begin{array}{l}\text { Quality } \\
\text { standards }\end{array}$ & $\begin{array}{c}\text { Analysis } \\
\text { Results }\end{array}$ \\
\hline & Logam TCLP & & & & \\
\hline 1 & Timbal, Pb & $\mathrm{mg} / \mathrm{L}$ & AAS & 0,5 & 0,71 \\
\hline 2 & Merkuri, $\mathrm{Hg}$ & $\mathrm{mg} / \mathrm{L}$ & AAS & 0,05 & $<0,0002$ \\
\hline 3 & Zink, Zn & $\mathrm{mg} / \mathrm{L}$ & AAS & 50 & $<0,05$ \\
\hline
\end{tabular}

Source: Results of the Research Center for Quality Research and Environmental Laboratory (P3KL2), Ministry of Environment and Forestry, 2017.

to the environment in accordance with Government Regulation No. 101 of 2014 . Thus, in terms of their chemical composition, recycling batteries fulfill the requirements for use as substitutes. concrete making aggregate.

\subsection{Equipment}

The process of making concrete waste of this battery can be seen in the picture $[1,2]$ and the process of maintenance and testing can be seen in the picture [3]

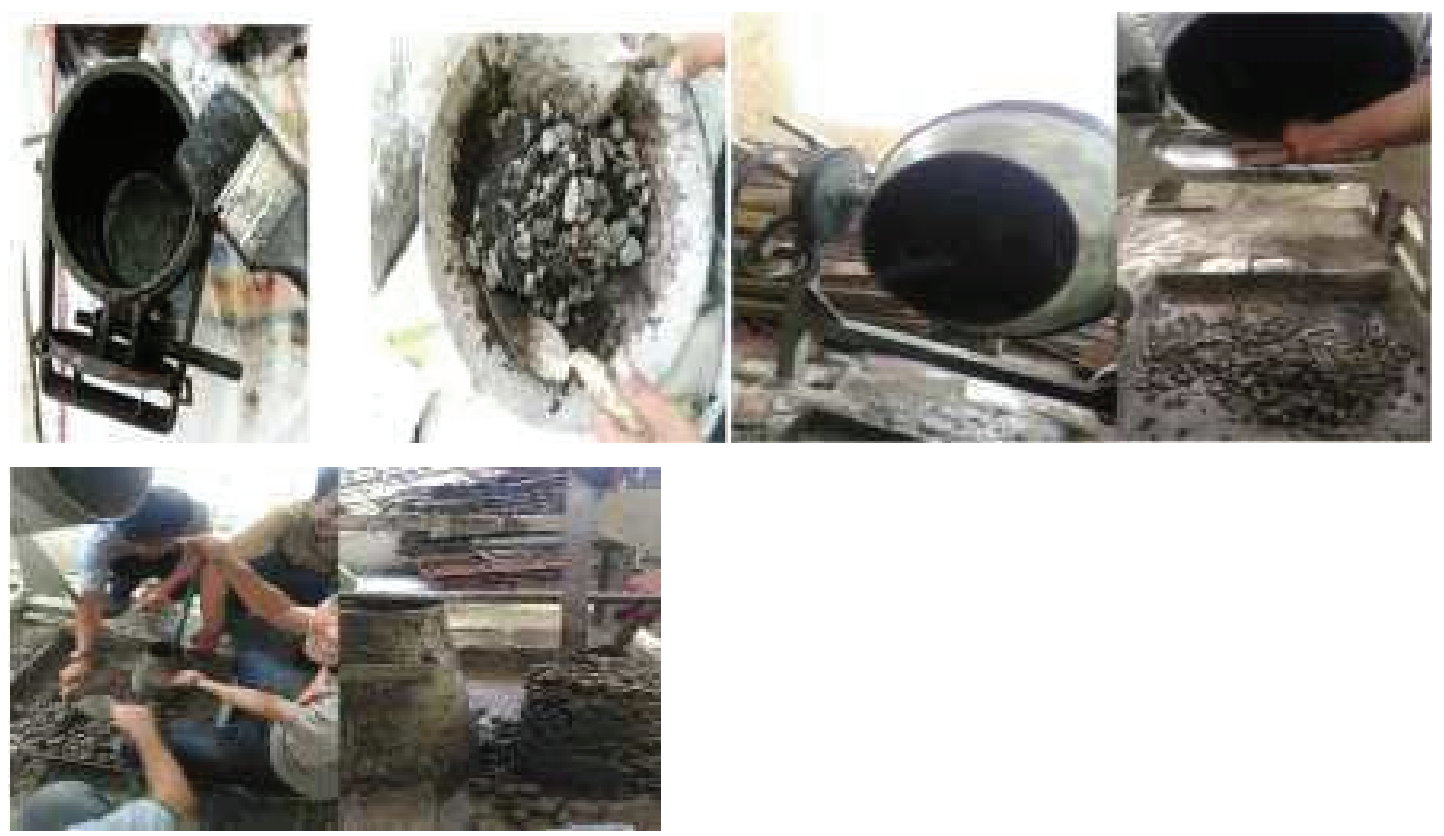

Figure 2: The process of making test specimens until slump testing.

\section{Results}




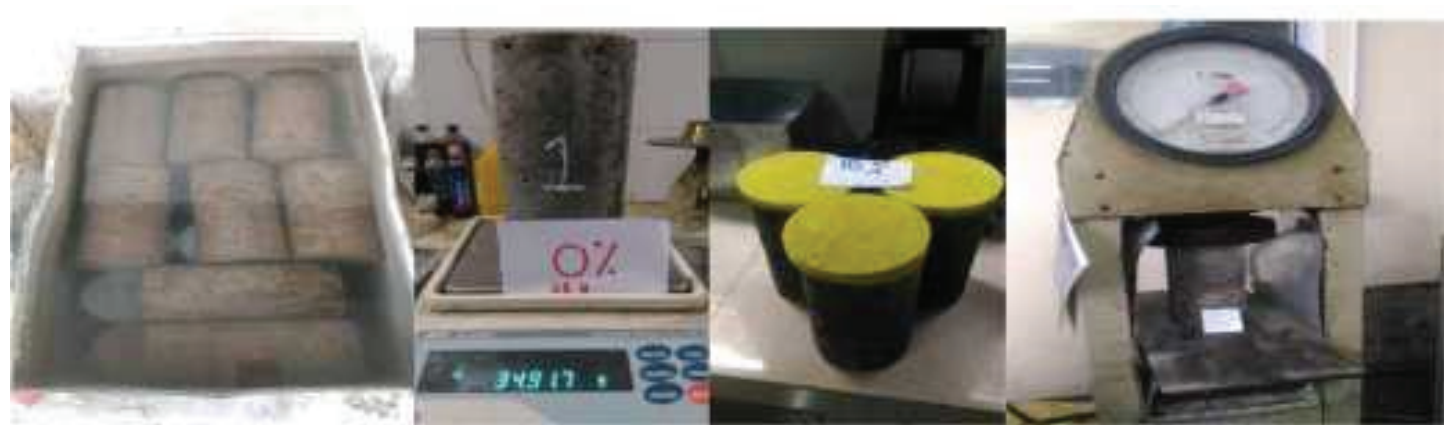

Figure 3: Concrete maintenance process and concrete compressive strength testing.

\subsection{Slump}

Slump testing is carried out on fresh concrete. Slump test is carried out immediately after mixing the concrete constituent materials, before printing the test object. The planned slump is $12+2$. The slump test results on fresh concrete in accordance with the plan, can be seen in Figure 4.

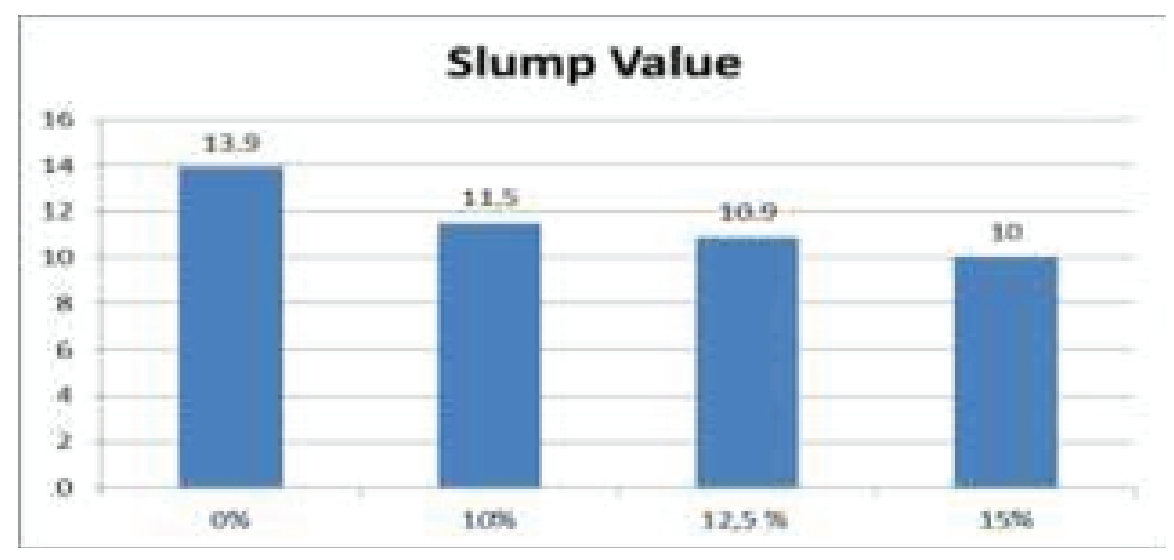

Figure 4: Slump value.

The results shown in Figure 4 show that the slump test value diagram decreases along with the addition of a variety of solid waste batteries in the concrete mixture. Decreasing the slump value will make the mixture more dense which affects workability. This is thought to be due to the initial nature of the solid waste of the battery which when reacted with water will bind water, so that the water that was originally planned to produce a blended mixture decreases in number due to the aggressiveness of the waste in terms of absorbing water. 


\subsection{Concrete weight}

Weighing the weight of the concrete contents is done after the concrete hardens and goes through the curing stage, then is removed and cleaned from dirt and dried. The following are the results of the weight of concrete content of 28 days for cylindrical volume with a diameter of $10 \mathrm{~cm}$ and a height of $20 \mathrm{~cm}$, can be seen in Table 3 .

TABLE 3: Results of Concrete Content Weight.

\begin{tabular}{|l|l|l|l|l|}
\hline Sample & \multicolumn{4}{|c|}{ Concrete Weight Results (kg) } \\
\hline & Accumulated Solid Waste Level \\
\hline & $\mathbf{0} \%$ & $\mathbf{1 0} \%$ & $\mathbf{1 2 , 5 \%}$ & $\mathbf{1 5 \%}$ \\
\hline 1 & 3,35 & 3,38 & 3,42 & 3,47 \\
\hline 2 & 3,29 & 3,44 & 3,49 & 3,45 \\
\hline 3 & 3,33 & 3,36 & 3,41 & 3,49 \\
\hline Average & 3,32 & 3,39 & 3,44 & 3,47 \\
\hline
\end{tabular}

\subsection{Compressive strength}

Diagram of concrete compressive strength testing with a variety of solid waste batteries can be seen in Table 4.

TABLE 4: Average Compressive Strength Chart of Concrete aged 28 days.

\begin{tabular}{l|c|c|c|c|}
\hline Sample & \multicolumn{4}{|c|}{ Compressive Strength (MPa) } \\
\hline & $\mathbf{0} \%$ & $\mathbf{1 0} \%$ & $\mathbf{1 2 , 5 \%}$ & $\mathbf{1 5 \%}$ \\
\hline 1 & 5,10 & 10,83 & 8,92 & 8.92 \\
\hline 2 & 3,82 & 3,18 & 7,64 & 8.28 \\
\hline 3 & 5,10 & 3,18 & 8,28 & 9.55 \\
\hline Average & $\mathbf{4 , 6 7}$ & $\mathbf{7 , 2 9}$ & $\mathbf{8 , 2 8}$ & $\mathbf{8 . 9}$ \\
\hline
\end{tabular}

From table 4 , it is found that the optimum compressive strength of 28 days is at a percentage of $15 \%$ with an average compressive strength of $8.9 \mathrm{MPa}$ and the smallest percentage at $10 \%$, which is an average compressive strength of $7.29 \mathrm{MPa}$. none of them produced close to $20 \mathrm{MPa}$, all the test results under the concrete quality of the 20 MPa plan.

In the 56-day-old concrete, the compressive strength increased due to the increase in the variety of solid waste of the battery. In the control concrete, the average compressive strength is $9.13 \mathrm{MPa}$, while concrete using solid waste of the battery is seen to increase. At a composition of $10 \%$, the average compressive strength was $22.08 \mathrm{MPa}$, up $141.85 \%$ from concrete dick, as well as the composition of $12.5 \%$ which experienced an increase 
TABLE 5: Average Compressive Strength Chart of Concrete aged 56 days.

\begin{tabular}{l|c|c|c|c|} 
Sample & \multicolumn{4}{|c}{ Compressive Strength (MPa) } \\
\hline & $\mathbf{0} \%$ & $\mathbf{1 0} \%$ & $\mathbf{1 2 , 5 \%}$ & $\mathbf{1 5 \%}$ \\
\hline 1 & 10.83 & 22.93 & 22.29 & 18.47 \\
\hline 2 & 12.74 & 19.75 & 29.30 & 18.47 \\
\hline 3 & 3.82 & 23.57 & 25.48 & 18.47 \\
\hline Average & $\mathbf{9 . 1 3}$ & $\mathbf{2 2 . 0 8}$ & $\mathbf{2 5 . 6 9}$ & $\mathbf{1 8 . 4 7}$ \\
\hline
\end{tabular}

of $181.5 \%$ from the control concrete and $15 \%$ composition which decreased up to 18.47 $\mathrm{MPa}$ from control concrete. The value of the optimum compressive strength produced is $25.69 \mathrm{MPa}$ from a variation of $12.5 \%$.

The maximum compressive strength (meeting the compressive strength of the plan is $20 \mathrm{MPa}$ ) when the concrete life of 28 days has not been fulfilled. After 56 days of concrete treatment, meet the compressive strength of the plan. This is influenced by the porosity of the concrete. Porous concrete will be weaker because the porosity of concrete is determined by the ratio of water and cement in the mixture $[4,5]$ It is assumed that compressive strength is not achieved due to slag absorbing a lot of water which causes the FAS value to decrease. The compressive strength value of concrete can also be influenced by the type of cement, the humidity condition of the air during the maintenance period of the test specimen, and the compacting of less than maximum specimens.

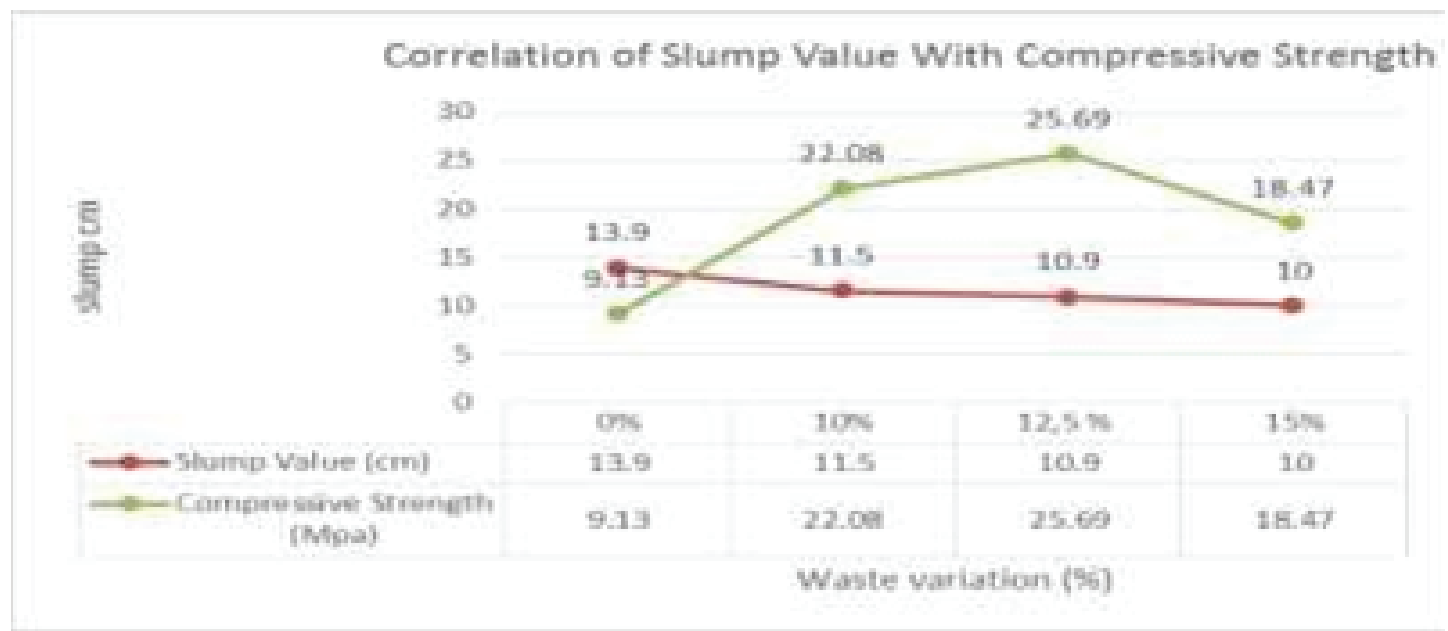

Figure 5: Correlation of Slump Value with Concrete Press Strength.

Based on Figure 5, it is shown in the graph that the greater the addition of variations in solid waste affects the slump value, the slump value tends to decrease in each additional variation of solid waste batteries. Allegedly because of the initial nature of 
solid waste batteries that bind water so that the concrete slump decreases with the addition of the composition.

Concrete with less water content will make the mixture uneven and even difficult to print [5] However, the addition of waste is quite influential on the cement sand compressive strength, presumably because the presence of $\mathrm{Pb}$ metal in recycled waste batteries in the form of slag can be solidified in cement sand media and will result in increased cement sand strength [1]

\section{Discussion}

Based on the results of the study and the discussion that has been carried out concluded that the recycling of solid waste (slag) batteries can be used as a substitute for some of the sand in a concrete mixture. Test results of concrete compressive strength with slag mixture can increase concrete compressive strength at 28 days. The highest concrete test results with slag are at a variation of $15 \%$, which is equal to $8.9 \mathrm{MPa}$. Different things on testing the compressive strength of concrete with slag mixtures on concrete 56 days old. The highest concrete test results with slag are at $12.5 \%$ variation, which is $25.69 \mathrm{MPa}$.

\section{Conclusion}

It can be concluded that the results shown in the diagram above that with the addition of the composition of recycled solid waste the battery will increase the compressive strength of the concrete. It is suspected that due to the initial nature of solid waste batteries which are reacted with water produce a mixture that is more sticky than the mixture of sand with water but not as sticky as a mixture of cement and water, so as to increase the compressive strength of concrete due to increased adhesion between constituent aggregates

\section{Funding}

This research work was supported by Research grant from Jakarta State University. 


\section{Acknowledgement}

The authors would like to thank their colleague for their contribution and support to the research. They are also to thank the technicians of the Material Testing Laboratory on Civil Engineering Program, Engineering Faculty, State University of Jakarta. And, thankful to all the reviewers who gave their valuable inputs to the manuscript and helped in completing the paper.

\section{Conflict of Interest}

The authors have no conflict of interest to declare.

\section{References}

[1] Purnawan, Hadi Prasetyo. 2014. Studi Evaluasi Proses Solidfikasi Limbah B3 dari Limbah padat (Slag) Industri Daur Ulang Aki Bekas pada Media Pasir Semen [Jurnal]. Yogyakarta: Fakultas Teknik, Institut Sains dan Teknologi AKPRIND Yogyakarta.

[2] Bayuseno, P. Athanasius. (2009). Evaluasi Proses Daur Ulang Sel Accu Bekas Serta Kualitas Produk Timbal [Jurnal]. Semarang: Universitas Diponegoro.

[3] Anonim. (2014). Peraturan Pemerintah Republik Indonesia No.101 Tahun 2014 Tentang: Pengelolaan Limbah Bahan Berbahaya Dan Beracun. Jakarta.

[4] A.M. Neville, J.M. Brooks. (1987). Concrete Technology. Singapore: Longman Singapore Publishers (Pte).

[5] Antoni, Nugraha, P. (2007). Teknologi Beton. Surabaya: Penerbit Andi. 